\title{
DETERMINATION OF PREDICTION EQUATIONS TO ESTIMATE BODY CONDITION SCORE FROM BODY SIZE AND TESTICULAR TRAITS OF YANKASA RAMS
}

\author{
A. Yakubu ${ }^{1}$, O.F. Fakuade ${ }^{1}$, E.A. Faith ${ }^{1}$, I.S. Musa-Azara ${ }^{2}$ and O.A. Ogunwole ${ }^{3}$ \\ ${ }^{1}$ Department of Animal Science, Faculty of Agriculture, Nasarawa State University, \\ Keffi, Shabu-Lafia Campus, P.M.B. 135, Lafia, Nasarawa State - Nigeria \\ ${ }^{2}$ Department of Animal Science, College of Agriculture, P.M.B. 33, Lafia, Nasarawa State - Nigeria \\ ${ }^{3}$ Department of Animal Science, University of Ibadan, 900001, Ibadan, Oyo State - Nigeria \\ Corresponding E-mail: abdulmojyak@gmail.com
}

Received March 15, 2013; Accepted May 26, 2013

\begin{abstract}
ABSTRAK
Penelitian bertujuan untuk mengembangkan model pendugaan nilai kondisi tubuh (NKT) dari bobot badan (BB), panjang testis (PT), diameter testis (DT) dan lingkar skrotum (LS) dengan menggunakan regresi linier berganda pada domba jantan Yankasa. Data diperoleh secara acak dari 120 ekor domba jantan berumur kira-kira 2,5 tahun yang dipelihara secara ekstensif pada peternakan di wilayah Narasawa, Nigeria. Meskipun korelasi fenotipik pairwise menunjukkan hubungan nyata (P0,01) antar variabel yang diukur, terdapat masalah kolinieritas antara BB dengan LT sebagaimana ditunjukkan oleh variance inflation factor (VIP) yang lebih besar daripada 10 (VIF $=19,45$ and 16,65 masingmasing untuk BB dan LS) dan tolerance value $(\mathrm{T})$ yang lebih kecil daripada $0,1(\mathrm{~T}=0,05$ and 0,06 masing-masing pada BB dan LS). Diantara variable kolinear, BB menunjukkan $83,7 \%$ keragaman pada NKT. Namun demikian sedikit perkembangan diperoleh pada pendugaan NKT dari BB dan PT [koefisien determinasi $\left(\mathrm{R}^{2}\right.$ ), adjusted $\mathrm{R}^{2}$ and root mean squares error (RMSE) masing-masing 85,3\%, $85,1 \%$ dan 0,305$]$. Pendugaan NKT domba jantan Yankasa dari BB dan ukuran-ukuran testis merupakan alat potensial untuk produksi dan pengembangan ruminansia kecil di Nigeria.

Kata Kunci: kondisi tubuh, sifat-sifat morfologi, Nigeria, regresi, domba
\end{abstract}

ABSTRACT

The study was aimed to develop prediction models using stepwise multiple linear regression analysis for estimating the body condition score (BCS) from the body weight (BW), testicular length (TL), testicular diameter (TD) and scrotal circumference (SC) of indigenous Yankasa rams. Data were obtained from 120 randomly selected rams with approximately two and half years of age, from different extensively managed herds in Nasarawa State, Nigeria. Although pairwise phenotypic correlations indicated strong association $(\mathrm{P}<0.01)$ among the measured variables, there was collinearity problem between BW and SC as revealed by the variance inflation factors (VIF) and tolerance valves (T). The VIT was higher than 10 (VIF $=19.45$ and 16.65 for $\mathrm{BW}$ and SC, respectively). The Twas smaller than $0.1(\mathrm{~T}=0.05$ and 0.06 in $\mathrm{BW}$ and $\mathrm{SC}$, respectively). BW was retained among the collinear variables, and was singly accounted for $83.7 \%$ of the variation in BCS. However, a slight improvement was obtained from the prediction of BCS from BW and TL [coefficient of determination $\left(\mathrm{R}^{2}\right)$, adjusted $\mathrm{R}^{2}$ and root mean squares error (RMSE) were $85.3 \%, 85.1 \%$ and 0.305 , respectively]. The prediction of the BCS of Yankasa rams from BW and testicular measurements could therefore be a potential tool for sustainable production and improvement of small ruminants in Nigeria.

Keywords: body condition, morphological traits, Nigeria, regression, sheep

\section{INTRODUCTION}

Livestock production in developing regions is generally characterized by small flock-size, communally shared grazing, uncontrolled mating, and the absence of pedigree and performance 
recording. The emphasis in the conservation of livestock breeds in developing regions should be to maintain diversity to meet current and future livelihood requirements (Yakubu and Ibrahim, 2011). Conservation priorities should be set in consultation with the farmers. Improvement in performance of small ruminant flocks or population over time can arise through improvement in management and feeding conditions, and through genetic progress of superior animals (Kosgey, 2004). The study and management of animal populations requires information about the factors affecting population dynamics. Information on the relative condition of individuals in a population over time is necessary to predict potential reproductive output or an impending increase or decline in numbers.

Body condition score (BCS) is an important measure of the fitness of an animal for assessing body reserves (quantity of fat and muscle) on a mature sheep. BCS and its use are important in terms of achieving the desired performance in certain physiological periods in sheep breeding where extensive conditions are dominant (Sezender et al., 2011), as it is useful for dietary management (Dorsten and Cooper, 2004) and can be used to assess the health status of animals (Hickman and Swan, 2010). Condition score uses manual palpation of tissue cover (muscle and fat) over the backbone and the short ribs (loin) immediately behind the last long ribs. Importantly, assessors also integrate the shape/fullness of the eye muscle between the backbone and ends of the short ribs with their assessment of tissue cover to allocate a score between 1 (very thin) and 5 (very fat) (Jefferies, 1961; Russel et al., 1969). In sheep, the BCS is correlated with a direct measurement of backfat depth or the proportion of fat in the animal body, providing a better estimate than body weight alone (Audige et al., 1998; van Burgel et al., 2011). However, BCS is not practised on farm as widely as it should be. This may partly due to dearth of trained specialists especially under the low-input farming systems of developing economies.

Information on body size and testicular traits of various breeds at constant age has paramount importance in the selection of genetically superior animals for production and reproduction purposes (Mekasha et al., 2008; Tariq et al., 2012). The biometrical analysis of testicular development is of great importance since it is significantly correlated with reproductive activity (Emsen,
2005; Koyuncu et al., 2005). In Soay sheep, males with large testes increase their share of paternities when receptive females are in abundance (Preston et al. 2011), presumably because they have better senses to find females rapidly and inseminate more sperm once a receptive female has been found.

Jefferies (1961) discussed the use of condition scoring in sheep management in particular situations, and although the scoring system has a very wide application, the relationships between particular condition scores and levels of individual animal performance are likely to vary between breeds and systems of management. Various traditional modelling approaches have been adopted to show the relationship among BCS, body size and testicular measurements (Cannas and Boe, 2003; Mekasha et al., 2008; Tariq et al., 2012). Although previous efforts had been made to show the association between body parameters in Nigerian indigenous sheep (Yakubu, 2010a; Yakubu, 2012), there was dearth of information on the relationship among BCS, body size and testicular measurements using regression analysis. Therefore, the present investigation was aimed to predict the BCS of Yankasa rams from body size and some testicular traits using stepwise multiple linear regression models.

\section{MATERIALS AND METHODS}

\section{Materials}

Data were obtained from 120 rams of the indigenous Yankasa sheep in their breeding tracts. The randomly selected animals which were approximately two and half years old, originated from different herds extensively managed in Nasarawa State, North Central Nigeria. Age was determined from the available livestock keeper's records and where information was missing, the age of each ram was estimated using dentition. The animals were grazed during the day on natural pasture containing forages such as northern gamba grass (Andropogon gayanus), stylo (Stylosanthes gracilis), leucaena (Leucaena leucocephala) and guinea grass (Panicum maximum), while their feeding was supplemented with dried yam peels when available. Records were taken on body condition score (BCS), body weight (BW), testicular length (TL) (largest dorso-ventral distance), testicular diameter (TD) (widest anterior-posterior distance) and scrotal circumference (SC) (widest part of the testes, after 
the testes had been firmly pushed into the scrotum) early in the morning before the animals were grazed. The BCS was determined based on a 5-point scale (ranging from 1 to 5 representing emaciated, poor, acceptable, fat or obese animals, respectively) as proposed by Jefferies (1961) and adopted by Russell et al. (1969).

BW was measured in kilograms (kg), using a hanging spring balance and a sack. The TL and TD were measured by using a vernier caliper and recorded in centimetres $(\mathrm{cm})$. The $\mathrm{SC}$ in centimetres $(\mathrm{cm})$ was measured by using a flexible tape. BW and testicular measurements were taken by the same person in order to avoid between-individual variations.

\section{Statistical analysis}

Descriptive statistics were computed for BCS, BW, TL, TD, and SC, respectively. The Spearman correlation coefficients were estimated to quantify the relationship between BCS and BW, TL, TD and SC. Due to the inadequacy of correlation as a method of detecting collinearity, the method of variance inflation factor (VIF) as reported in Yakubu (2011b) was employed as follows:

$\mathrm{VIF}=1 /\left(1-\mathrm{R}^{2}\right)$ where $\mathrm{R}^{2}=$ coefficient of determination.

A further step for testing collinearity was to calculate the tolerance $(\mathrm{T})$ value. To obtain measures of tolerance, each independent variable was treated as a dependent variable and regressed on the other independent variables. The $\mathrm{R}^{2}$ was used to calculate T (Aziz and Sharaby, 1993) as follows:

$\mathrm{T}=1-\mathrm{R}^{2}$

where,

$\mathrm{R}^{2}=$ coefficient of determination.

The multiple linear regression model adopted to detect the presence or absence of collinearity was:

$\mathrm{Y}=\mathrm{a}+\mathrm{b}_{1} \mathrm{X}_{1}+\mathrm{b}_{2} \mathrm{X}_{2}+\mathrm{b}_{3} \mathrm{X}_{3}+\mathrm{b}_{4} \mathrm{X}_{4}+\mathrm{e}$

where,

$\mathrm{Y}=$ dependent or endogenous variable (BCS)

a $=$ intercept

$\mathrm{b}=$ regression coefficients

$\mathrm{X}=$ independent or exogenous variables $(\mathrm{BW}$, TL, TD, SC)

$\mathrm{e} \quad=$ random error associated with each record (normally, independently and identically distributed with zero mean and constant variance).

The following model described by Weisberg (1985) was employed to delete redundant variables arising from collinearity:

$\mathrm{RV}=|\mathrm{Bj}| / 6$

where,

$\mathrm{RV}=$ redundant variable.

$\mathrm{Bj} \quad=$ regression coefficient of $\mathrm{Xj}$ variable.

$6=$ square root of residual mean square of the full regression model $(\mathrm{BW}, \mathrm{TL}, \mathrm{TD}$ and $\mathrm{SC}$ inclusive).

The eventual regression models were fitted using stepwise multiple regression analysis. Each model was assessed using $\mathrm{R}^{2}$, adjusted $\mathrm{R}^{2}$ and RMSE (Root mean squares error). SPSS (2010) statistical package was employed in the analysis.

\section{RESULTS AND DISCUSSION}

The descriptive statistics of BCS, BW, TL, TD and SC are summarized in Table 1. BCS appears to be the most useful determinant of several reproductive and productive outcomes (Audige et al., 1998). It is important to have information about BCS in all physiological periods to determine the feeding programs to be applied in order to increase lamb production by indigenous sheep breeds, and to allow sheep to feed with balanced ration in different

Table 1. Descriptive Statistics of Body Weight, Body Condition Score and Testicular Measurements of Yankasa Rams

\begin{tabular}{lrcc}
\hline \multicolumn{1}{c}{ Traits } & Mean & Standard Deviation & Coefficient of Variation (\%) \\
\hline Body condition & 2.73 & 0.79 & 28.94 \\
Body weight, $\mathrm{kg}$ & 35.10 & 7.23 & 20.60 \\
Testicular length, cm & 6.53 & 1.51 & 23.12 \\
Testicular diameter, cm & 4.85 & 1.10 & 22.68 \\
Scrotal circumference, cm & 26.34 & 5.81 & 22.06 \\
\hline
\end{tabular}


Table 2. Spearman Correlation Coefficients of Body Condition Score, Body Weight and Testicular Measurements of Yankasa Rams**

\begin{tabular}{lccccc}
\hline \multicolumn{1}{c}{ Traits } & BCS & BW & TL & TD & SC \\
\hline BCS & & 0.85 & 0.78 & 0.78 & 0.83 \\
BW & & 0.76 & 0.91 & 0.98 \\
TL & & & 0.79 & 0.74 \\
TD & & & & 0.89 \\
\hline
\end{tabular}

$\mathrm{BCS}=$ body condition score, $\mathrm{BW}=$ body weight, $\mathrm{TL}=$ testicular length, $\mathrm{TD}=$ testicular diameter $\mathrm{SC}=$ scrotal circumference, ** Significant at $\mathrm{P}<0.01$ for all coefficients

physiological periods (Cannas and Boe, 2003). Higher variations in all body parameters of the present study might be due to the individual performance differences of the rams. Rajuana et al. (2008) noted that the causes of phenotypic variation in traits of farm animals are due to genetic and environment effects, and the joint effect of genotype and environment. In addition, large variation within certain measurements might suggest the absence of selection.

The phenotypic correlations $(r=0.78-0.85)$ of BCS with other body parameters were positive and highly significant $(\mathrm{P}<0.01)$ (Table 2$)$. BCS was more highly correlated with BW $(r=0.85)$ and SC $(r=0.83)$ compared to TD and TL, respectively ( $\mathrm{r}=0.78$ in both cases). Keith et al. (2009) and Tariq et al. (2012) reported in goats and sheep that the phenotypic correlations between BCS and BW were statistically significant. Testicular measurements were positively related to $\mathrm{BCS}$ and $\mathrm{BW}$ in the present study. This observation suggests that high energy intake makes males fit at mating (SchulteHostedde et al., 2005; Waye and Mason, 2008; Rajuana et al., 2008; Fernandez et al., 2010). The size of mammalian testes during the mating period is a product of their potential capacity for sperm production and their degree of seasonal activation (Preston et al., 2011). Testosterone production will be dependent on the condition of individuals, with only males that are capable of meeting the energetic requirements of producing 'costly' T-mediated sexual ornaments being able to do so (Andersson, 1994; Duckworth et al., 2001; Perez-Rodriguez et al., 2006).

Parameter estimates, VIF and $\mathrm{T}$ of body measurements to estimate BCS of Yankasa rams are presented in Table 3. A bivariate correlation matrix of explanatory variables might not be sufficient to identify collinearity problems because near linear dependencies may exist among more complex combinations of regressors (Belsley, 1980). This informs the use of the VIF which represents the increase in variance due to high correlation between the predictors (Yakubu, 2010b; Tariq et al., 2011). Although no absolute standard exists for judging the magnitude of the VIF, a crude rule of the thumb, according to Gill (1986), is to be suspicious of collinearity if VIF is greater than 10.00. In the present study, VIFs gave the first indication of the existence of severe collinearity in BW and SC (VIF = 19.45 and 16.65 for $\mathrm{BW}$ and $\mathrm{SC}$, respectively). The tolerance values $(\mathrm{T}=0.05$ and 0.06 in $\mathrm{BW}$ and $\mathrm{SC}$, respectively) confirmed collinearity problem since they were smaller than the value 0.10 , which is an indication that collinearity may have more than a trivial impact on the estimates of the regression parameters (Gill, 1986; Aziz and Sharaby, 1993). Collinearity implies that the effect of one predictor cannot be uniquely identified (i.e., is nearly confounded with the effect of another predictor). For instance, the statistical model can include only one of the two predictors (St-Pierre, 2007). According to Weisberg (1985), the deletion of variables with small $\mid \mathrm{Bj} / / 6$ in the regression models would be desirable. This improves the accuracy and robustness of the prediction models. In the present study, the respective values obtained for BW and $\mathrm{SC}$ were 0.39 and 0.15 . Due to the higher value of $\mathrm{BW}$, it was retained for the subsequent stepwise regression analysis alongside TL and TD.

The stepwise regression models revealed that BW singly accounted for $83.7 \%$ of the variation in BCS (Adjusted $\mathrm{R}^{2}$ and RMSE were 83.6 and 
Table 3. Parameter Estimates, Variance Inflation Factors (VIF) and Tolerance Values (T) of Body Size and Testicular Dimensions for Estimating Body Condition of Yankasa Rams

\begin{tabular}{lcccccl}
\hline \multicolumn{1}{c}{ Trait } & Estimate & S.E. & Significance & VIF & T & \multicolumn{1}{c}{ Remarks } \\
\hline Intercept & -0.841 & 0.137 & 0.001 & - & - & - \\
BW & 0.117 & 0.017 & 0.001 & 19.454 & 0.051 & Collinearity \\
TL & 0.146 & 0.038 & 0.001 & 4.382 & 0.228 & Non-collinearity \\
TD & -0.052 & 0.063 & 0.412 & 6.436 & 0.155 & Non-collinearity \\
SC & -0.045 & 0.019 & 0.021 & 16.649 & 0.060 & Collinearity \\
\hline
\end{tabular}

S.E. $=$ standard error

Table 4. Stepwise Regression Models for the Prediction of Body Condition Score in Yankasa Rams

\begin{tabular}{lcccc}
\hline \multicolumn{1}{c}{ Model } & $\mathrm{R}^{2}(\%)$ & Adjusted $\mathrm{R}^{2}(\%)$ & $\mathrm{RMSE}$ & $\mathrm{P}$-value \\
\hline $\mathrm{BCS}=-0.775+0.100 \mathrm{BW}$ & 83.7 & 83.6 & 0.320 & $\mathrm{P}<0.01$ \\
$\mathrm{BCS}=-0.825+0.079 \mathrm{BW}+0.121 \mathrm{TL}$ & 85.3 & 85.1 & 0.304 & $\mathrm{P}<0.01$ \\
\hline
\end{tabular}

$\mathrm{BCS}=$ body condition score, $\mathrm{BW}=$ body weight, $\mathrm{TL}=$ testicular length, $\mathrm{R}^{2}=$ coefficient of determination, $\mathrm{RMSE}=$ root mean square error, $\mathrm{P}=$ significant level

0.320 , respectively) (Table 4). There was, however, a slight improvement in the prediction of BCS from BW and TL $\left[\mathrm{R}^{2}\right.$, adjusted $\mathrm{R}^{2}$ and Root mean squares error (RMSE) were 85.3\%, $85.1 \%$ and 0.305 , respectively]. There is a workable relationship between change in liveweight and change in condition score across a wide range of genotypes and environments (van Burgel et al., 2011). In a related study, Young et al. (2011) reported that it is important for producers to be able to discriminate between leaner sheep because the condition score fluctuates between scores 2 and 3 and small changes in condition score within this range have considerable impact on animal welfare and on whole-farm profitability. The present findings are congruous to the submissions of earlier workers on the possible prediction from one another of BCS, BW and testicular dimensions (Sezenler et al., 2011; Tariq et al., 2012); and this could be exploited in animal husbandry and selection of breeding stock under low-input farming systems in tropical and subtropical conditions.

\section{CONCLUSION}

The study revealed the potential effectiveness to predict the BCS of Yankasa rams from body size and testicular measurements using stepwise multiple regression. Therefore, in the selection of rams for mating purposes, BCS, BW and testes measurements could jointly be taken as important criteria and management support tool for selection of superior animals for sustainable production and improvement of animal genetic resources.

\section{REFERENCES}

Agga, G.E., U. Udala, F. Regassa and A. Wudie. 2011. Body measurements of bucks of three goat breeds in Ethiopia and their correlation to breed, age and testicular measurements. Small Rumin. Res. 95:133-138.

Andersson, M. 1994. Sexual Selection. Princeton University Press, Princeton, New Jersey.

Audige, L., P.R. Wilson and R.S Morris. 1998. A body condition score system and its use for farmed red deer hinds. A body condition score system and its use for farmed red deer hinds. N. Z. J. Agric. Res. 41:545-553.

Aziz, M.A. and M.A. Sharaby. 1993. Collinearity as a problem in predicting body weight from body dimensions of Najdi sheep in Saudi Arabia. Small Rumin. Res. 12:117-124.

Belsley, D.A., E. Kuh and R.E. Welsch. 1980. 
Regression diagnostics: Identifying influential data sources of collinearity. 1st Edition, John Wiley and Sons, New York. Pp. 292.

Cannas, A. and F. Boe. 2003. Prediction of the relationship between body weight and body condition score in sheep. Ital. J. Anim. Sci. 2 (suppl. 1):527-529.

Dorsten, C.M. and D.M. Cooper. 2004. Use of body condition scoring to manage body weight in dogs. Comtemp. Top. Lab. Anim. Sci. 43:34-37.

Duckworth, R.A., M.T. Mendonca and G.E. Hill. 2001. A condition dependent link between testosterone and disease resistance in the house finch. Proc. Royal Soc. B-Biol. Sci. 268:2467-2472.

Emsen, E. 2005. Testicular development and body weight gain from birth to 1 year of age of Awassi and Redkaraman sheep and their reciprocal crosses. Small Rumin. Res. 29:7982.

Fernandez, A., R. Soriguer, F. Carro and E. Castien. 2010. Relation between physical condition and reproductive activity in a population of Iberian hares, Lepus granatensis in northern Iberian Peninsula. Folia Zool. 59:1-8.

Gill, J.L. 1986. Outliers and influence in multiple regression. J. Anim. Breed. Genet. 103: 161175.

Hickman, D.L. and M. Swan. 2010. Use of a body condition score technique to assess health status in a rat model of polycystic kidney disease. J. Am. Assoc. Lab. Anim. Sci. 49: 155-159.

Jefferies, B.C. 1961. Body condition scoring and its use in management. Tasm. J. Agric. 39: 19-21.

Keith, L., C. Okere, S. Solaiman and O. Tiller. 2009. Accuracy of predicting body weight from body conformation and testicular morphometry in pubertal Boer goats. Res. J. Anim. Sci. 3:26-31.

Kosgey, 1.S. 2004. Breeding objectives and breeding strategies for small ruminants in the tropics. Ph.D thesis Animal Genetic and Breeding Group, Wageningen University.

Koyuncu, M., S.K. Uzun, S. Ozis and S. Duru. 2005. Development of testicular dimensions and size, and their relationship to age and body weight in growing Kivircik (Western Thrace) ram lambs. Czech. J. Anim. Sci. 50:243-248.
Mekasha, Y., A. Tegegne, A. Abera and H. Rodriguez-Martinez. 2008. Body size and testicular traits of tropically-adapted bucks raised under extensive husbandry in Ethiopia. Reprod. Domest. Anim. 43:196206.

Perez-Rodriguez, L., J. Blas, J. Vinuela, T.A. Marchant and G.R. Bortolotti. 2006. Condition and androgen levels: are condition-dependent and testosteronemediated traits two sides of the same coin? Anim. Behav. 72:97-103.

Preston, B.T., I.R. Stevenson, G.A. Lincoln, S.L. Monfort, J.G. Pilkington and K. Wilson. 2011. Testes size, testosterone production and reproductive behaviour in a natural mammalian mating system. J. Anim. Ecol. doi: 10.1111/j.1365-2656.2011.01907.x

Rajuana, A.K., M.R. Tayabur, J.G., Wilson K., M.A. Hoque, S.S. Husain and Sultana Z. 2008. Repeatability estimates for seminal traits and their phenotypic relationships with testes measurements and performance traits in black Bengal buck. Bang. J. Anim. Sci. 37:34-41.

Russel, A.J.F., J.M. Doney and R.G. Gunn. 1969. Subjective assessment of body fat in live sheep. J. Agric. Sci. (Cambridge) 72:451454.

Schulte-Hostedde, A.I., J.S. Millar and G.J. Hickling. 2005. Condition dependence of testis size in small mammals. Evol. Ecol. Res. 7:143-149.

Sezenler, T., M. Ozder, M. Yildirir, A. Ceyhan and M.A. Yuksel. 2011. The relationship between body weight and body condition score in some indigenous sheep breeds in turkey. The J. Anim. Plant Sci. 21:443-447.

SPSS. 2010. Statistical Package for Social Sciences. SPSS Inc., 444 Michigan Avenue, Chicago, IL60611.

St-Pierre, N.R. 2007. Meta-analyses of experimental data in the animal sciences. $\mathrm{R}$. Bras. Zootec. 36:343-358.

Tariq, M.M., E. Eyduran, M.A. ,Plant Sciences.A. Bajwa, A. Waheed, F. Iqbal and Y. Javed. 2012. Prediction of body weight from testicular and morphological characteristics in indigenous Mengali sheep of Pakistan using factor analysis scores in multiple linear regression analysis. Int. J. Agric. Biol. 14:590-594.

Van Burgel, A.J., C.M. Oldham, R. Behrendt, M. Curnow, D.J. Gordon and A.N. Thompson 
2011. The merit of condition score and fat score as alternatives to liveweight for managing the nutrition of ewes. Anim. Prod. Sci. 51:834-841.

Waye, H.L and R.T. Mason. 2008. A combination of body condition measurements is more informative than conventional condition indices: Temporal variation in body condition and corticosterone in brown tree snakes (Boiga irregularis). Gen. Comp. Endocrin. 155: 607-612.

Weisberg, S. 1985. Applied linear regression. $2^{\text {nd }}$ Edition, John Wiley and Sons Publishers, New York, USA. Pp. 196.

Yakubu, A. 2012. Application of regression tree methodology in predicting the body weight of Uda sheep. Animal Science and Biotechnologies 45: 484-490.

Yakubu A. 2010a. Path coefficient and path analysis of body weight and biometric traits in Yankasa lambs. Slovak J. Anim. Sci. 43:17-25.

Yakubu, A. 2010b. Fixing multicollinearity instability in the prediction of body weight from morphometric traits of White Fulani cows. J. Cent. Eur. Agric. 11:487-492.

Yakubu, A. and I.A. Ibrahim. 2011. Multivariate analysis of morphostructural characteristics in Nigerian indigenous sheep. Ital. J. Anim. Sci. 10:83-86.

Young, J.M., A.N. Thompson, M. Curnow and C.M. Oldham. 2011. Whole-farm profit and the optimum maternal liveweight profile of Merino ewe flocks lambing in winter and spring are influenced by the effects of ewe nutrition on the progeny's survival and lifetime wool production. Anim. Prod. Sci. 51:821-833. 